\title{
ANALISE DO CAMPO TÉRMICO DA CIDADE DE IRATI/PR: PRIMEIROS EXPERIMENTOS PARA A DEFINIÇÃO DO CLIMA URBANO.
}

\author{
Aparecido Ribeiro de Andrade ${ }^{14}$ \\ Wilson Flávio Feltrim Roseghini ${ }^{15}$ \\ Francisco de Assis Mendonça ${ }^{16}$
}

\begin{abstract}
RESUMO
O presente trabalho trata do planejamento urbano de cidades de porte médio a pequeno e, de forma particular, analisa a formação do campo térmico urbano com base na análise climática. A cidade de Irati, localizada na porção centrosudeste do estado do Paraná, constitui-se no objeto deste estudo. Considerando-se o referencial teórico que trata sobre a temática, tanto no aspecto mais geral (planejamento urbano), como no específico (clima urbano), foi efetuado um levantamento preliminar das características essenciais do sítio urbano da cidade em questão. Após tal levantamento, foi possível escolher pontos de coletas de dados de temperatura para 12 locais diferentes, os quais foram monitorados por acadêmicos do curso de Geografia da Unicentro, no período de 23 a 30 de abril de 2008. As características físicas da cidade permitiram concluir que a mesma apresenta um relevo ondulado e orientações de vertentes variadas, não sendo possível definir um padrão uniforme. Por outro lado, as características socioeconômicas permitem afirmar que o adensamento urbano está concentrado na área central da cidade, com uma incipiente ocupação nas áreas periféricas, pelo menos no que se refere a impermeabilização do solo. Dessa forma, os 12 pontos escolhidos para coleta de dados possibilitaram a análise de diferentes realidades socioambientais da cidade, dando condições para se analisar a influência da dinâmica urbana na variação do campo térmico. As análises dos resultados e as conclusões obtidas permitiram identificar a formação de ilhas de calor dentro da área de estudo; em princípio, a área mais quente está localizada na região central da cidade, mas, ao mesmo tempo no período noturno, se torna uma área sem diferenciação com o seu entorno e, até mesmo, apresentando valores de temperatura que induzem à formação de uma ilha de frescor. A influência da estrutura urbana na variabilidade espacial da temperatura do ar foi verificada,

${ }^{14}$ Professor Assistente Mestre do Departamento de Geografia da Universidade Estadual do CentroOeste - UNICENTRO, Campus de Irati-PR. Doutorando em Geografia pelo Departamento de Geografia da UFPR, Curitiba-PR. E-mail: apaandrade@gmail.com

${ }^{15}$ Professor Colaborador Mestre do Departamento de Geografia da Universidade Estadual do CentroOeste - UNICENTRO, Campus de Irati-PR. Doutorando em Geografia pelo Departamento de Geografia da UFPR, Curitiba-PR. E-mail: feltrim@hotmail.com

${ }^{16}$ Professor Titular do Departamento de Geografia da UFPR, Curitiba-PR. E-mail: chico@ufpr.br
\end{abstract}


embora sobre ela paire dúvidas quanto à gênese, pois os fatores físicos (relevo, vegetação e água) parecem influenciar tanto quanto a estrutura urbana, na sua formação. Para uma maior segurança quanto à analise, novos experimentos devem ser realizados, utilizando métodos e metodologias diferenciadas, procurando uma melhor explicação para a variação dos elementos climáticos na cidade de Irati.

Palavras-chaves: clima urbano - temperatura do ar - conforto térmico - Irati

\begin{abstract}
This work deals with the urban planning of cities to medium-sized and small, in particular, examines the formation of urban thermal field analysis based on climate. The city of Irati, located in south-central portion of Parana State, is the object of this study. Considering the theoretical references on which the subject, both in terms of more general (urban planning), and in particular (urban environment), was made a preliminary survey of the essential characteristics of the urban site of the city concerned. After the survey, were selected from collections of data points of temperature at 12 locations, which were monitored by the academic progress of Geography of Unicentro in the period from 23 to 30 April 2008. The physical characteristics of the city showed a sloping geomorphology with guidelines for different sections, showed no uniform pattern. Moreover, the socioeconomic conditions show that the urban density is concentrated in the central area of the city, with a low occupancy in peripheral areas, at least with regard to sealing of soil. Thus, the 12 items selected for collection of data allowed the analysis of different social realities of the city, which examine the influence of urban dynamics in the temperature change. The analysis of results and conclusions have identified the formation of heat islands within the study area; in principle, the hottest area is located in the central city, but at the same time at night, it is an area without distinction to your surroundings and even presenting values of temperature that induce the formation of a cooling island. The influence of urban structure in the spatial variability of air temperature was examined, although there are still doubts about the genesis, because the physical factors (topography, vegetation and water) seem to influence both on the urban structure in their formation. For greater certainty as to the study, new experiments should be conducted, using different methods and methodologies, seeking a better explanation for the variation of climatic elements in the city of Irati.
\end{abstract}

Key-words: urban climate, air temperature, thermal comfort, Irati.

\title{
INTRODUÇÃO
}

Os estudos de geografia contemporâneos dão bastante ênfase a realidade das cidades, que constituem formas evidentes de transformação da paisagem natural, pois é neste espaço que as alterações e influências da sociedade humana se tornam cada vez mais visíveis. As modificações ocorridas nos elementos do clima, por exemplo, possuem grande repercussão ecológica, 
creditadas, principalmente, ao fato de afetar de maneira imediata os habitantes, seja através do desconforto térmico ou mesmo pela produção acelerada e constante de poluentes que se concentram em áreas prejudiciais à paisagem urbana, deteriorando a qualidade de vida dos cidadãos.

Um dos aspectos mais comuns em investigações voltadas à temática do clima urbano é o fenômeno da ilha de calor, que se caracteriza pelo aumento da temperatura do ar nas cidades em relação ao meio rural e também na diferenciação entre regiões diferentes da área urbana, separadas por critérios mais ou menos aleatórios, mas centrados no uso e ocupação da terra. Por isto, as áreas menos urbanizadas normalmente apresentam gradientes de temperatura diferentes das mais urbanizadas. Na mesma linha de raciocínio, áreas com maior concentração de atividades comerciais e industriais, tendem a apresentar especificidades marcantes, de acordo com seus respectivos ambientes.

Habitualmente, sobretudo em cidades de pequeno e médio porte, as maiores diferenciações ocorrem no centro das cidades, onde as construções tendem a formar um mosaico de casas e prédios mais adensados, propiciando alterações na dinâmica dos elementos do clima, principalmente no elemento relacionado à variação ou variabilidade da temperatura do ar, tanto espacial quanto temporal.

A intensidade ou magnitude das ilhas de calor e/ou frescor geralmente evoluem mediante a diferença máxima observada, em um determinado momento, entre a temperatura de um ponto qualquer da cidade e outros com especificidades diferenciadas. Tal técnica permite comparar áreas diferentes e, se monitorada por um tempo suficiente, dá subsídios a um possível planejamento urbano, priorizando a mitigação de efeitos desagradáveis, causados pelo maior adensamento das construções na cidade.

Neste contexto, a cidade de Irati, localizada na porção centro-sudeste do Estado do Paraná, foi selecionada como objeto de estudo deste trabalho. Com aproximadamente 60 mil habitantes, é a cidade pólo de uma micro-região, apresentando grande fluxo comercial, agrícola e universitário, o que vem promovendo uma expansão significativa da malha urbana nos últimos anos.

A identificação da variabilidade espacial intra-urbana da temperatura do ar foi realizada e os resultados apontaram para uma influência do sítio urbano na distribuição das temperaturas. Fatores como relevo, disposição das vertentes e densidade dos fluxos urbanos, evidenciaram forte relação com o campo térmico na área pesquisada, resultando em uma marcada amplitude entre topos e fundos de vale e principalmente entre área central e o parque da cidade, possibilitando inferir sobre a existência de uma ilha de calor.

Através da distribuição de pontos de coleta de dados em áreas do perímetro urbano com diferentes atributos sociais e naturais, buscou-se identificar a dinâmica da ocorrência de ilhas de calor/frescor, permitindo assim uma possível identificação de influências da urbanização em uma cidade de pequeno porte. Essa influência foi investigada a partir da diferenciação altimétrica entre os pontos, localizados em áreas com densidades urbanas variadas, procurando demonstrar a relação dessas características com o relevo.

O presente estudo justifica-se pela falta de dados científicos, tanto do ponto de teórico quanto empírico sobre a realidade urbana de Irati. As poucas referências encontradas estão centradas na discussão sobre a evolução histórica e econômica da cidade. 
O trabalho foi organizado de forma a fazer um resgate teórico sobre o planejamento urbano e o clima das cidades (tópico I), procurando enfatizar a bibliografia especializada que trata do tema e contextualizar a realidade nacional associada.

No tópico II, foram apresentados os materiais e métodos, que consistiram na escolha de pontos de coletas de dados de temperatura dentro da área urbana de Irati e posterior monitoramento através de termômetros. Monitoramentos que foram feitos em três horários diários.

Os resultados do monitoramento efetuado foram discutidos (tópico III) e as análises permitiram a identificação de diferenciações no campo térmico na cidade de Irati. A gênese da ocorrência de possíveis ilhas de calor e/ou frescor não foram bem identificadas, mas os objetivos do trabalho foram alcançados, principalmente no que tange a possibilidade do início de um diagnóstico socioambiental que propicie tomadas de decisão no planejamento urbano.

\section{O Planejamento urbano e o clima das cidades.}

O planejamento das cidades brasileiras, desde 1920, obedeceu a lógica da influência de escolas do pensamento científico externas, ou seja, os trabalhos e teorias produzidos por urbanistas alemães, franceses, norte-americanos e ingleses, foram tomados como referência. A escola alemã, representada por Simmel, Weber, Benjamin e Daus, foi a que menos marcas deixou entre os estudiosos da urbanização brasileira. Entretanto, uma ala de estudiosos com ascendência marxista, como Max Weber, deixou profundas reflexões sobre a realidade urbana, mas não logrou êxito em produzir concepções de novos modelos de cidades (FREITAG, 2006).

Santos (1991, 1994 e 2008), também de ascendência marxista, principalmente na Geografia, estudou a estrutura urbana de algumas cidades brasileiras, mostrando quão perversa era a relação de produção do espaço urbano, priorizando determinadas classes sociais.

A escola francesa foi a que mais influenciou o pensamento de urbanistas brasileiros, mas somente no aspecto de "revitalizar" centros urbanos, que começavam a apresentar sinais de esgotamento na capacidade de absorver o excedente populacional oriundo das mais diversas regiões, principalmente para as metrópoles do Rio de Janeiro e de São Paulo. Seguindo esta mesma tendência, a escola norte-americana também criou seguidores, principalmente com o processo de verticalização das construções urbanas, tendo os shopping centers como grande expoente. Por fim, a escola inglesa, que não foi tão influente no planejamento de grandes cidades brasileiras, mas teve papel crucial na colonização de várias regiões do Brasil, principalmente no sul e sudeste, através de companhias dirigidas por empresas inglesas, que usaram muito da lógica do planejamento londrino nas suas áreas de influência (FREITAG, op. cit.).

Como se vê, as teorias que influenciaram o planejamento urbano das cidades brasileiras, na maioria das vezes, buscaram resolver o problema da cidade enquanto oferta de oportunidades capitalistas, seja na questão do espaço para moradias, seja na maior possibilidade de dividendos nas atividades comerciais e industriais. Os problemas sociais da cidade foram sendo resolvidos de forma paliativa e nunca definitiva. Somente na década de 1990, 
principalmente após a ECO-92, é que o planejamento urbano agregou à suas teorias, os ideais do planejamento ambiental, considerado numa perspectiva holística.

Em se tratando das modificações das condições naturais relacionadas ao aspecto climático, os gregos e os romanos, na antiguidade clássica, já conheciam as alterações climáticas produzidas pelas atividades humanas. Luke Howard e Emilien Renou, foram os primeiros a realizar estudos de Climatologia Urbana, em cidades na Inglaterra e França, respectivamente. Estes estudos datam do início do século XIX e não utilizavam dados de estações meteorológicas para diagnosticar o efeito da urbanização no clima da cidade. Londres mostrou ser $2,2^{\circ} \mathrm{C}$ mais quente que seus arredores e Paris $1,0{ }^{\circ} \mathrm{C}$ mais quente (GOMEZ et al., 1993 apud BRANDÃO, 1996).

O clima das cidades apresenta condições geoecológicas bem específicas (ilhas de calor como referencial) e o planejamento urbano tardou para inserir preocupações com as causas e efeitos dessas especificidades. Entretanto, a partir de década de 1980 as cidades brasileiras começam a ser estudadas nesta perspectiva, surgindo algumas reflexões sobre tal temática, propondo metodologias de análise geográfica e buscando soluções aos problemas apontados.

O processo de urbanização das cidades, com seu acelerado crescimento populacional, acarreta alterações na atmosfera urbana. Estas alterações ocorrem em função das atividades sociais, tais como emissão de poluentes, atividades industriais intensas, supressão da vegetação nativa, adensamento populacional, dentre outros fatores. Estas ações, direta ou indiretamente, favorecem a formação de microclimas diferenciados, em diferentes localidades da cidade, ocorrendo assim o fenômeno da ilha de calor ou mesmo da ilha de frescor, dependendo da magnitude e da forma em que os eventos ocorrem (MENDONÇA, 1995). Este clima específico gerado nas cidades é designado clima urbano, mas também conhecido simplesmente como clima das cidades.

Uma proposição metodológica tipicamente geográfica, para abordar as questões do clima relacionadas com o ambiente urbano, é o Sistema Clima Urbano (S.C.U.), onde o estudo dos aspectos climáticos da cidade sob uma perspectiva conjuntiva e integradora possibilita apontar os atributos fundamentais que particularizam os estados atmosféricos que, em contraste com os espaços circundantes, se observam graças às interferências urbanas, prendendo-se a concepção de clima à dos estados médios atmosféricos sobre dado lugar, delineando uma preocupação sistêmica para as características do clima (MONTEIRO, 1976).

O SCU foi criado e é utilizado especificamente para análises de clima urbano, mas pode ser considerado como uma ferramenta de investigação científica genuinamente ambiental, pois considera todos os aspectos relativos ao ambiente natural sem, contudo, abandonar as características sociais relevantes à avaliação do local a ser estudado. Obviamente que outras tantas metodologias abordaram e abordam a problemática ambiental, mas como o foco de interesse deste estudo não é, necessariamente voltado às discussões ambientais de forma mais ampla, mas para o clima urbano especificamente, é conveniente utilizar essa referência como norteadora teórica.

A proposta do SCU não foi criada a partir de um estudo de caso, mas sim depois da reflexão sobre o problema gerado pelas edificações urbanas, principalmente aqueles vinculados à qualidade de vida urbana. O autor da 
proposta já fez uma crítica sobre sua aplicabilidade e ressaltou que foram necessários mais de 15 anos, após sua proposição, para que a comunidade geográfica brasileira fizesse uso, de forma cabal, de suas teorias. As dificuldades técnicas e operacionais na coleta de dados climáticos e também sociais, sobrepuseram a vontade de vários estudiosos que tentaram estudar o clima da cidade, utilizando os princípios do SCU.

Somente no início da década de 1990, surgiram trabalhos empíricos utilizando o SCU como referência e, inclusive, ampliando suas propostas. Algumas teses de doutoramento foram defendidas a partir dessa década, gratificando o criador da proposta, ao encontrar no ano de 1998, quando da realização do III Seminário de Climatologia Geográfica - em Salvador, 38 trabalhos de Climatologia Urbana, utilizando vários princípios do SCU. Foi nesse momento que a Climatologia Geográfica reconheceu, de forma cabal, a importância do SCU, culminando com o avanço de trabalhos sobre climas urbanos das cidades brasileiras (MONTEIRO e MENDONÇA, 2003).

Mesmo não utilizando a proposta do SCU, outros pesquisadores brasileiros realizaram trabalhos voltados para o tema Clima Urbano.Tarifa (1977), em seu estudo sobre a cidade de São José dos Campos no período de 02/12/74 a 10/12/74 (verão), observou que quando a área estava sob o domínio dos sistemas atmosféricos extratopicais (Sistema Polar Atlântico (SPA)), a temperatura máxima absoluta foi de $30,6^{\circ} \mathrm{C}$ e as diferenças de temperatura urbano-rural ocorriam com valores entre 1,0 a $3,4^{\circ} \mathrm{C}$ e a umidade relativa com diferenças entre 2 a $12 \%$ na média diária - coincidindo com menor teor de umidade do ar na área urbana, gerando desconforto térmico.

Outro trabalho que se juntou a esta temática, foi aquele realizado na cidade de São Paulo, que identificou a ocorrência de ilhas de calor em vários pontos da cidade, resultando em uma análise climática numa cidade que já constava entre as três maiores do mundo. Esse estudo efetuou um comparativo, não só da diferenciação climática da área rural com o meio urbano, mas propôs e comprovou que existe uma amplitude térmica entre diferentes áreas dentro da estrutura urbana (LOMBARDO, 1985).

Naquele caso a comprovação da existência da ilha de calor foi conseguida, além de se propor uma dinâmica intra-urbana para aspectos climáticos. Vários outros pesquisadores da temática, seguindo raciocínio metodológico parecido, analisam a estrutura interna das cidades com relação ao chamado conforto térmico. Diferentes estudos abordaram e abordam essa variável ambiental, tão importante para o bem-estar da população.

Mais centrado nos pressupostos do SCU, foi realizado o estudo do clima urbano da cidade de Londrina, norte do Paraná, onde foi possível identificar a geração de ilhas de calor e de frescor em uma cidade de porte médio com características regionais voltada para as atividades agropastoris. A tese desenvolvida frisou que o uso e ocupação da terra foram fatores primordiais na influência da geração de ilha de calor e/ou frescor, pois áreas densamente edificadas apresentaram ilhas de calor, mas em contrapartida áreas destinadas a parques e lagos, mesmo que dentro do limite urbano, foram responsáveis pela geração de ilhas de frescor. Da mesma forma, a diferenciação entre o urbano e o rural foi facilmente encontrada (MENDONÇA, 1995).

A partir dessas contribuições e muitas outras não citadas, ocorreu a reflexão acerca do ambiente urbano, tanto por parte dos autores, como por seus futuros orientados. A lógica do planejamento urbano, principalmente aquela 
relacionada à qualidade de vida urbana, passou a ser uma questão amplamente discutida nos trabalhos, tentando encontrar respostas ao planejamento da cidade enquanto habitat natural da sociedade humana. O uso e ocupação da terra, tanto no intra-urbano como nos seus arredores, se colocou como investigação norteadora de diagnósticos socioambientais.

A dualidade entre a defesa da natureza primeira e a manutenção da qualidade de vida depois de sua transformação - a cidade como exemplo, não esgotam as discussões acerca de seus problemas. Um mesmo evento natural pode apresentar efeitos diferentes em ambientes urbanos parecidos, mas com uma realidade social e cultural diferente. Cidades do mesmo porte, mas com estruturas internas diferenciadas, receberão o impacto de um terremoto, por exemplo, de forma distinta. Após a década de 1980, as abordagens teóricas e práticas sobre a organização e o planejamento das cidades, sempre buscaram um maior e melhor equilíbrio entre o ambiente natural e o social, tentando encontrar a chamada "cidade saudável". Nesta perspectiva e tomando o SCU como teoria norteadora, foi proposto o Sistema Ambiental Urbano - S.A.U., onde,

Todo um complexo fluxo de matéria e energia, de origem natural e/ou produto da ação humana, interage permanentemente no contexto urbano e dinamiza as formas com que se manifestam elementos da natureza e da sociedade humana na cidade, formando a materialidade urbana. ... (MENDONÇA, 2004, p. 199).

O SAU se propõe a estudar as interações entre a natureza e a sociedade, considerando principalmente a diversidade escalar da manifestação de problemas ambientais advindos da relação socidade-natureza nas cidades. A proposta propõe uma evolução das idéias de diversos autores, inclusive alguns dos já citados, culminando com um padrão esquemático para abordar todas as variáveis que estão em permanente relação dentro do ambiente urbano, indo desde atividades econômicas, até tomadas de decisão do poder público, sem desconsiderar os aspectos naturais (relevo, vegetação, solo, água e ar).

A evolução das metodologias de análise urbana, num contexto dos fenômenos naturais, denota uma certa relação causal enriquecedora na análise integrada dos fatos geográficos em si. O conhecimento da realidade urbana não pode ser fragmentado, pois tanto os aspectos sociais como naturais devem fazer parte do esboço metodológico de análise, principalmente porque

[...] A cidade sempre teve relações com a sociedade no seu conjunto, com sua composição e seu funcionamento, com seus elementos constituintes (campo e agricultura, poder ofensivo e defensivo, poderes políticos, Estados, etc), com sua história. Portanto, ela muda quando muda a sociedade no seu conjunto. [...] (LEFEBVRE, 2001, p. 51).

A cidade é considerada como algo material, substrato que está sobre o solo, recebendo energia e matéria do subsolo e da atmosfera, mas sempre vinculada às relações sociais, limitadas pela vontade da sociedade humana e não "determinadas" por ela. Os limites impostos pelas vontades sociais não 
configuram uma relação unilateral, pois a complexidade das relações naturais com as sociais, vão definir o ambiente urbano.

Dessa forma o planejamento urbano e o clima local estão interligados, pois a estrutura urbana influencia o ciclo hidrológico, que por sua vez afeta o conforto ambiental. Essa relação se dá através da impermeabilização, da diminuição de áreas verdes e da poluição atmosférica nas cidades, causando o fenômeno das ilhas de calor, que está associado ao aumento da pluviosidade urbana no verão, contribuindo, num círculo vicioso, para o acirramento do problema das enchentes. Vale mencionar outro problema climático urbano que é a desumidificação, causada, sobretudo, pela diminuição da evapotranspiração com a eliminação da vegetação.

Considerando o planejamento urbano brasileiro de forma mais ampla, deixando de centrar a discussão nas questões climáticas, vale ressaltar que

...não faz muito sentido falar de um 'sistema' brasileiro de planejamento urbano, uma vez que: 1) a ancoragem legal da política urbana nos planos nacional (por enquanto, essencialmente, apenas os artigos 182 e 183 da Constituição Federal, o Estatuto da cidade e lei 6766/79, que cuida do parcelamento do solo) e estadual (constituições estaduais) é pequena; 2) muitos municípios sequer possuem um plano diretor e, mesmo quando possuem, as leis e diretrizes municipais relativas ao planejamento urbano (...) variam enormemente entre um município e outro, tanto no espírito quanto na qualidade. ... (SOUZA, 2006, p. 408).

A experiência brasileira em planejamento urbano sofre de condições estruturais históricas, pois as decisões que deveriam ser centradas nos representantes do povo (Estado) são fragmentadas e não seguem a lógica da representatividade popular. As iniciativas de planejamento obedecem à vontade da política regional e favorecem grupos seletos, normalmente vinculados a agentes imobiliários. Tal procedimento é adotado em discussões que englobam pólos regionais, numa perspectiva mais geral (Brasil como um tudo), mas os modelos decisórios atingem também as pequenas cidades.

A obrigatoriedade da existência de um Plano Diretor, principalmente após a edição do Estatuto da Cidade (Lei 10257, de 10 de outubro de 2001), tentou mudar a realidade nacional, incentivando alguns instrumentos urbanísticos, como o IPTU Progressivo, supostamente capaz de dar ao Poder Público melhores condições de regular a produção e apropriação do espaço urbano segundo critérios mais democráticos e socialmente justos. O Estatuto estabelece a necessidade de mecanismos de gestão democrática e participativa das cidades, por exemplo, oficializando a obrigatoriedade do Orçamento Participativo.

A cidade de Irati, com sua estrutura de formação vinculada a grupos heterogêneos do ponto de vista cultural (descendentes de europeus, em sua maioria), tendo as atividades agrícolas como principal fonte de acumulação de renda e de poder, viu sua sede urbana evoluir de forma totalmente desorganizada, onde as melhores áreas foram ocupadas por uma minoria privilegiada em detrimento da maioria, sem acesso a renda e ao poder.

A falta de participação popular nas decisões sobre o planejamento urbano, quando existia, foi a tônica do crescimento da cidade. Esta circunstância, aliada ao desinteresse político e econômico em administrar os 
problemas oriundos do crescimento urbano de forma mais criteriosa, culminaram com o surgimento de uma ocupação da terra desorganizada, seguindo o modelo nacional.

\section{MATERIAL E MÉTODOS}

O município de Irati se encontra na região Centro-sul do Paraná (Figura 01), a 812 metros de altitude; com área territorial de $995,289 \mathrm{~km}^{2}$. Irati foi desmembrado do município de Imbituva e sua instalação foi em 15/07/1907, conforme os dados do Instituto Paranaense de Desenvolvimento Econômico e Social (IPARDES, 2008).

A principal atividade econômica do município de Irati é a agricultura, seguida pela indústria madeireira e pelo comércio. O clima de Irati é do tipo Cfb (segundo classificação de Koppen), ou seja, clima temperado, onde há freqüentes geadas no inverno, com temperaturas médias máximas de $24,2^{\circ} \mathrm{C}$; médias mínimas de $11,0^{\circ} \mathrm{C}$, médias mensais de precipitação pluviométrica de $194 \mathrm{~mm}$ e média mensal de umidade relativa do ar de 79,6\% (PREFEITURA MUNICIPAL DE IRATI, 2008).

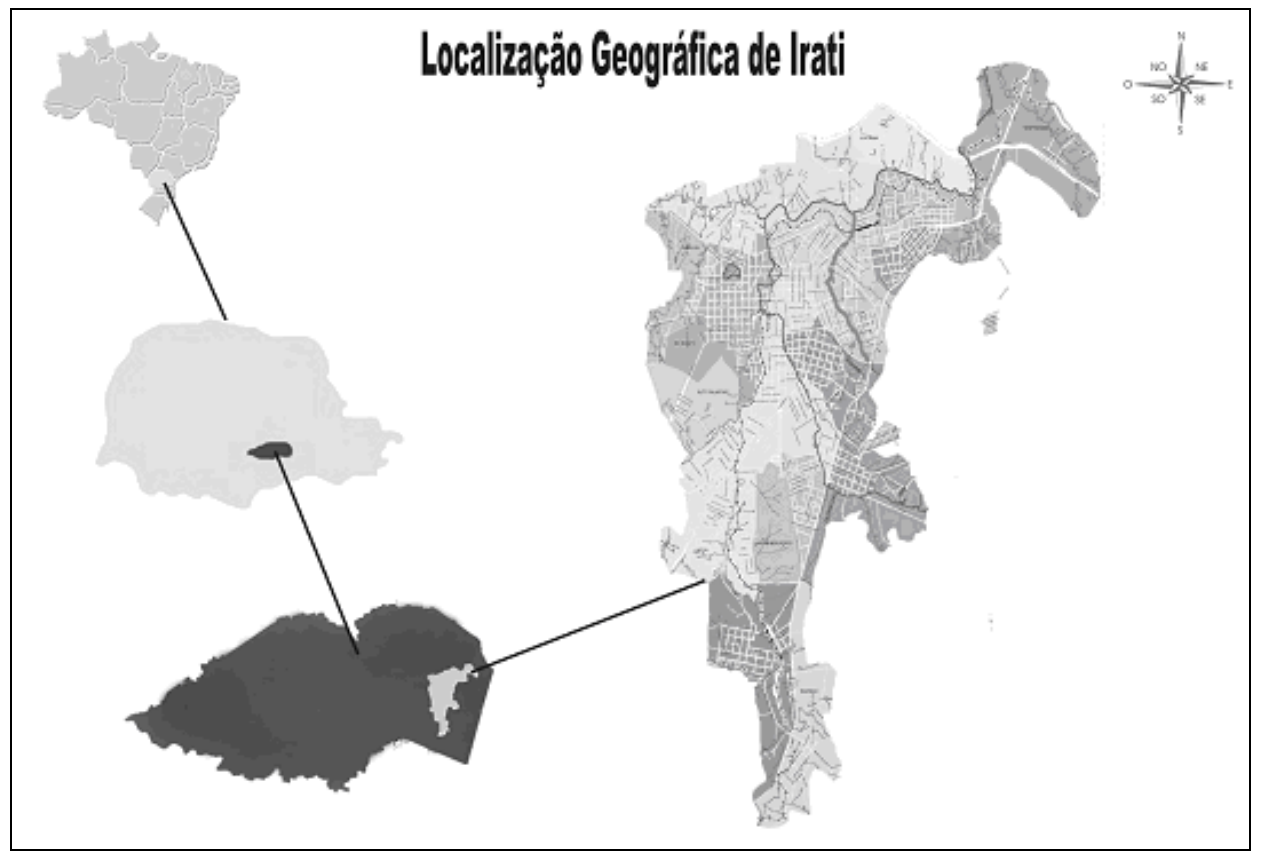

Figura 01: Localização da cidade de Irati, a partir do território brasileiro Fonte: Prefeitura Municipal de Irati (sem escala)

Segundo o último censo, fornecido pelo Instituto Brasileiro de Geografia e Estatística (IBGE, 2008), no ano de 2007, Irati contava com uma população de 54.151 habitantes, mostrando um crescimento considerável, em relação a 1980, quando o município contava com 42.227 habitantes.

O censo de 2000 , realizado pelo IBGE, mostra que $75,10 \%$ da população iratiense habita na área urbana da cidade e, somente $24,90 \%$ dos habitantes do município, residem em área rural. Isso mostra que, apesar de Irati ser uma área 
fortemente agrícola, a maior parte da população encontra-se no perímetro urbano (PREFEITURA MUNICIPAL DE IRATI, 2008).

José Maria Orreda (1981) explana que a temperatura chega a seguinte variação: a mínima de $-5^{\circ} \mathrm{C}$, até a máxima de $38^{\circ} \mathrm{C}$. E as chuvas, segundo o autor, baseado em dados que foram coletados na época, são mais freqüentes de setembro a fevereiro.

O climatograma elaborado para Irati, a partir de dados cedidos pelo Instituto Nacional de Meteorologia - INMET, possibilita identificar valores médios de temperatura centrados em mínimos no mês de julho $\left(7,9^{\circ} \mathrm{C}\right)$ e máximos no mês de janeiro $\left(27,3^{\circ} \mathrm{C}\right)$. Ressalta-se, assim, uma amplitude térmica média bem significativa, pois o mês mais frio (julho) tem um decréscimo de $19,4^{\circ} \mathrm{C}$ em relação ao mês mais quente (janeiro). A precipitação também apresenta uma variação média bem parecida, em que o mês mais é janeiro, e o mês menos chuvoso, é agosto. Dessa forma, o mês mais quente é o mais chuvoso, mas o mais frio não é o mais seco, mas essa relação nem sempre é possível de ser verificada e nem é objetivo deste trabalho (Figura 02 ).

Também centrado em dados do INMET, foi possível identificar que a média da temperatura para os dias escolhidos para monitoramento de campo, foi de: dia $23 / 04\left(18,4{ }^{\circ} \mathrm{C}\right)$; dia 24/04 (18,8 $\left.{ }^{\circ} \mathrm{C}\right)$; dia $25 / 04\left(18,1{ }^{\circ} \mathrm{C}\right)$; dia 26/04 $\left(16,5{ }^{\circ} \mathrm{C}\right)$; dia $27 / 04\left(19,4{ }^{\circ} \mathrm{C}\right)$; dia $28 / 04\left(21,1{ }^{\circ} \mathrm{C}\right)$; dia 29/04 (18,7 $\left.{ }^{\circ} \mathrm{C}\right)$; Dia 30/04 (15,3 $\left.{ }^{\circ} \mathrm{C}\right)$. Ressalta ainda, que nos dias 26, 27, 29 e 30/04 ocorreram precipitações, que se concentraram mais nos últimos dois dias $(88,4 \mathrm{~mm})$, enquanto nos dois primeiros dias choveu somente $8,8 \mathrm{~mm}$.

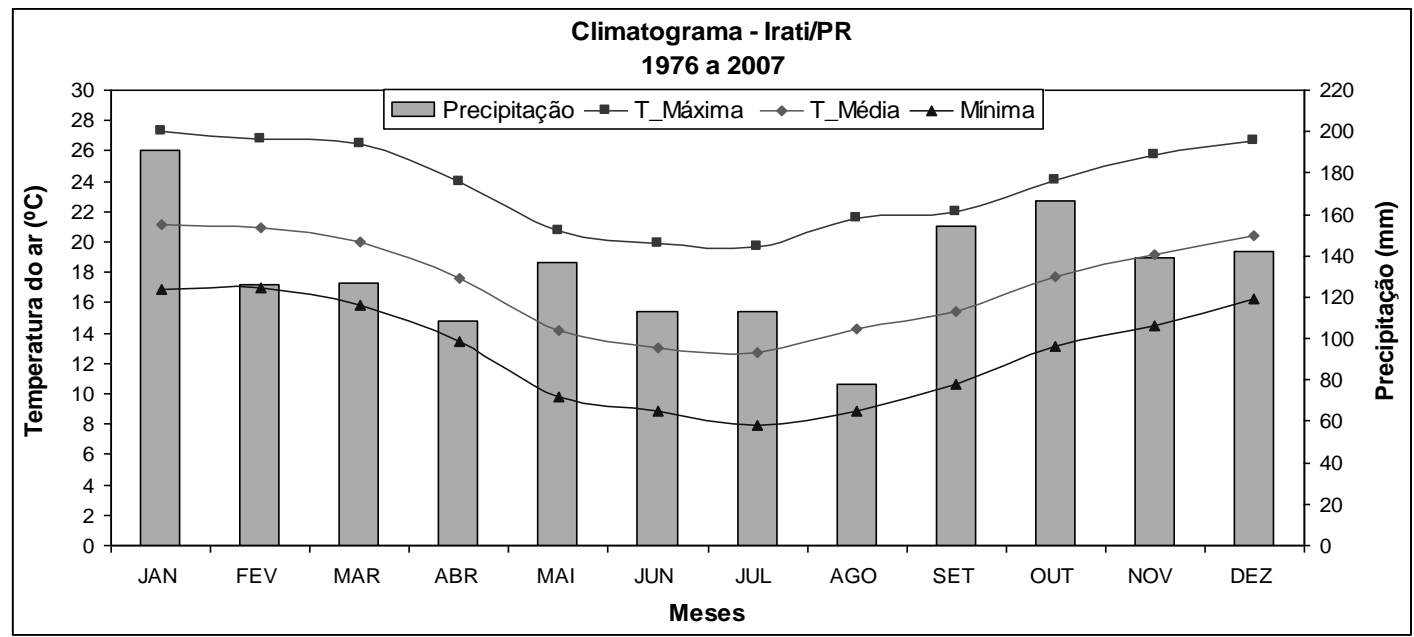

Figura 02: Climatograma da cidade de Irati (1976-2007)

Fonte: INMET (2008)

A partir da identificação da divisão de bairros da cidade de Irati, procedimento centrado nos pressuposto por Monteiro (1990), em que as particularidades da cidade, tanto sociais como naturais foram identificadas e consideradas, e contando com o apoio de alunos voluntários do curso de Geografia da Unicentro, tentou-se fazer uma distribuição dos pontos de coleta de dados com a melhor distribuição espacial possível, objetivando representar diferentes realidades da dinâmica urbana (Figura 03). 


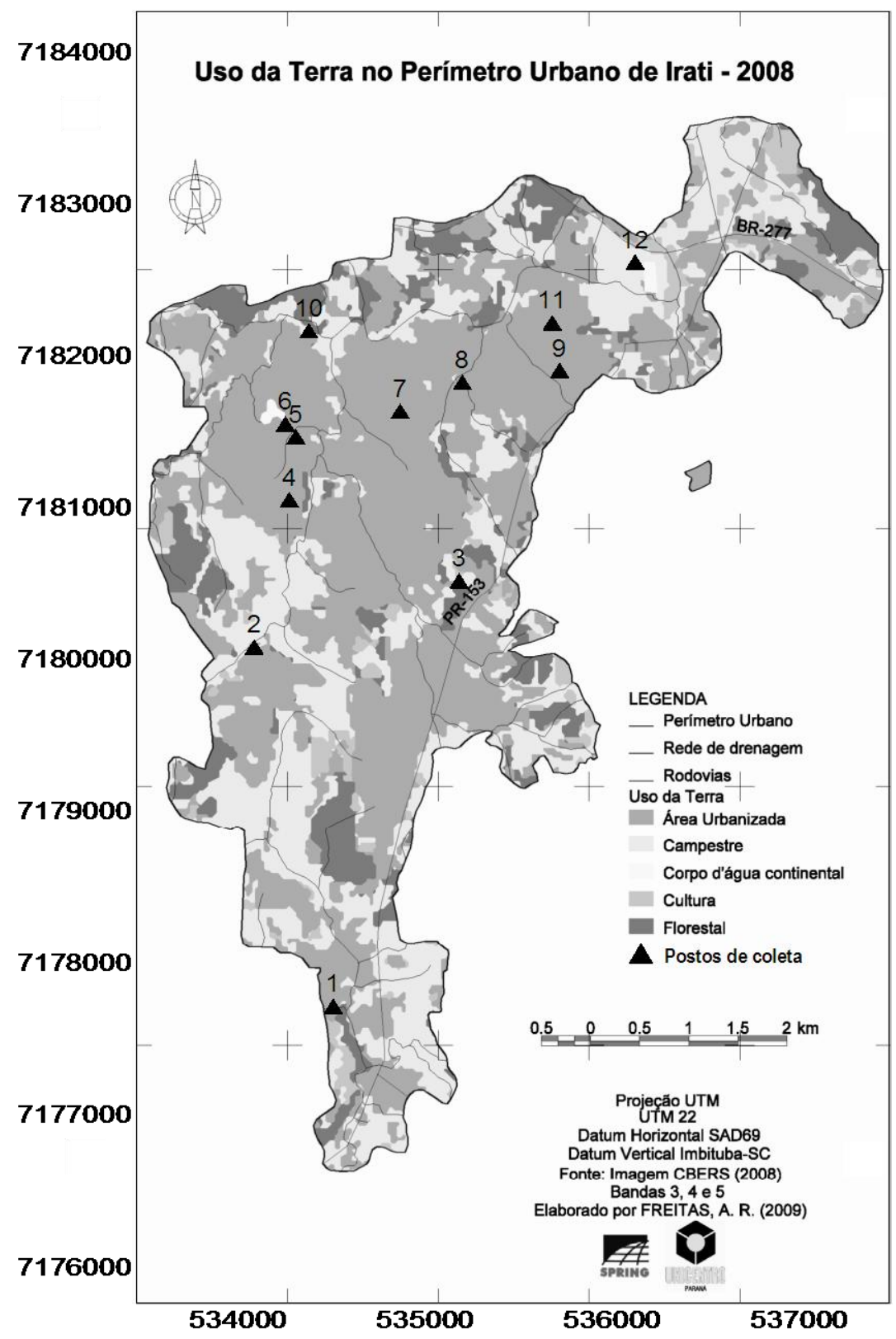

Figura 03: Distribuição espacial dos pontos de coleta de dados e uso da terra.

Esse procedimento enfatiza as características geoecológicas, entendidas enquanto junção do substrato físico onde a cidade está e os aspectos mais ligados à sua urbanização. Nota-se que os pontos 5, 6, 7 e 8 estão em áreas totalmente urbaizadas e sem nenhuma influência da vegetação ou corpos d'água. Além disso, a área onde foram instalados os postos de coleta, está bem no meio da região central da cidade. Os outros pontos, por sua vez, além de contemplar uma melhor distribuição espacial, possuem influências das mais diversas, tanto naturais (altitude, orientação das vertentes, vegetação e água), como sociais (densidade de casas e comércios em geral). 
O georreferenciamento dos pontos de coleta foi efetuado através de um receptor GPS, onde foram adquiridas informações locacionais e altimétricas.

O Ponto 1 representa uma área periférica com altitude de 830 metros, localizado na área rural do município e dentro do campus da universidade. O Ponto 2 (860m) está inserido em uma área industrial pouco adensada, ou seja, existem poucas edificações e as atividades realizadas nas indústrias são incipientes. O Ponto $3(870 \mathrm{~m})$ se localiza em um bairro periférico, com pouca concentração de moradias. Os pontos 4 a 8 estão localizados na área central da cidade, em áreas com cotas altimétricas variando de 817 a 850 metros. Os pontos 9 a 12 estão localizados em bairros periféricos com cotas variando entre 810 a 870 metros devido ao relevo ondulado e ao vale do Rio das Antas, principal rio na área urbana.

Cada um dos pontos foi monitorado por um aluno voluntário no período de 23 a 30 de abril de 2008 (outono), ficando responsável pela coleta de dados diários de temperatura em três horários (09h00min; 15h00min; e 21h00min). Esta pesquisa foi elaborada dentro da disciplina de Tópicos I - Clima Urbano, onde os acadêmicos receberam instruções baseadas nos conceitos propostos para estudos de clima urbano, obedecendo ao mínimo aceitável de critérios para disposição de termômetros, aquisição e análise dos dados coletados.

Foram utilizados termômetros da marca Incoterm, que medem temperatura do ar no intervalo de $-10,0^{\circ} \mathrm{C}$ a $+50,0{ }^{\circ} \mathrm{C}$, com precisão de $1,0{ }^{\circ} \mathrm{C}$, pesando $45 \mathrm{~g}$ e medindo $230 \times 80 \times 10 \mathrm{~mm}$. Tais aparelhos foram instalados em áreas a $1,5 \mathrm{~m}$ do solo, protegidos da insolação e precipitação, com suas frentes orientadas para o quadrante Sul.

Após a coleta dos dados de temperatura nos três horários distintos, os mesmos foram organizados através de mapas de isolinhas de temperatura, dentro da área de estudo, de forma a permitir a visualização da variabilidade espacial do campo térmico de Irati. Este procedimento foi realizado através do Software Surfer 8.0, que utiliza o método Kriging de interpolação.

\section{RESULTADOS E DISCUSSÃO}

A discussão dos resultados do presente estudo será amparada na análise das isotermas, representadas através de cartogramas que apresentam sua distribuição espacial na área urbana da cidade de Irati, assim como da análise dos sistemas atmosféricos atuantes no período.

Segundo CPTEC (2010), sistemas frontais, um ciclone extratropical e a configuração do jato em baixos níveis contribuíram para a ocorrência de elevados totais de precipitação e baixas temperaturas na Região Sul do país no mês de abril de 2008, principalmente no final desse período.

O quarto sistema frontal do mês foi o que mais influenciou o período analisado nessa pesquisa. Esse sistema deslocou-se desde o litoral da Argentina, intensificado pela presença dos jatos em baixos e altos níveis da atmosfera. A atuação conjunta destes sistemas ocasionou temporais na Região Sul e a massa de ar frio associada afetou significativamente nas temperaturas, principalmente nos dias 25, 26 e 30 de abril.

Assim, ao analisar as Figuras 04 a 11, representativas dos dados de temperatura do ar coletados no das 09h00min, nota-se que existe uma grande variabilidade diária. A temperatura não varia temporalmente, pois tanto os 
valores mínimos de temperatura, quanto os máximos não apresentam um padrão bem definido dentro do período, fato que se deve ao curto período de análise, não permitindo a observação de maiores mudanças no tempo. Entretanto, a variabilidade espacial no mesmo horário de coleta é facilmente notada.

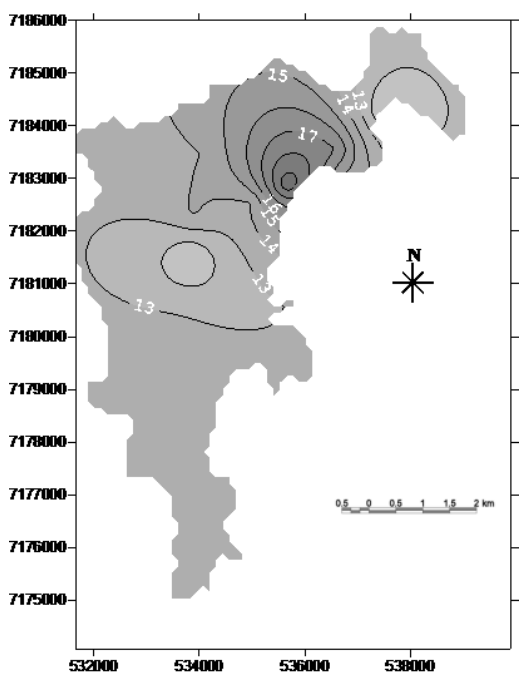

Figura 04: Temperatura $\left({ }^{\circ} \mathrm{C}\right)$ às 09 horas do dia 23/04/2008

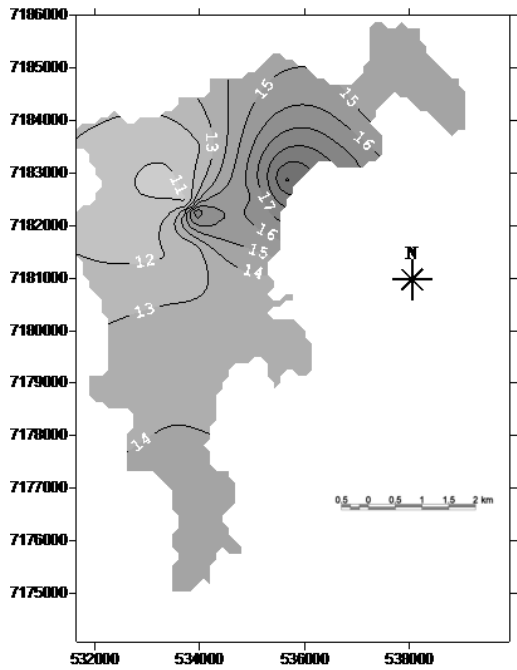

Figura 06: Temperatura $\left({ }^{\circ} \mathrm{C}\right)$ às 09 horas do dia 25/04/2008

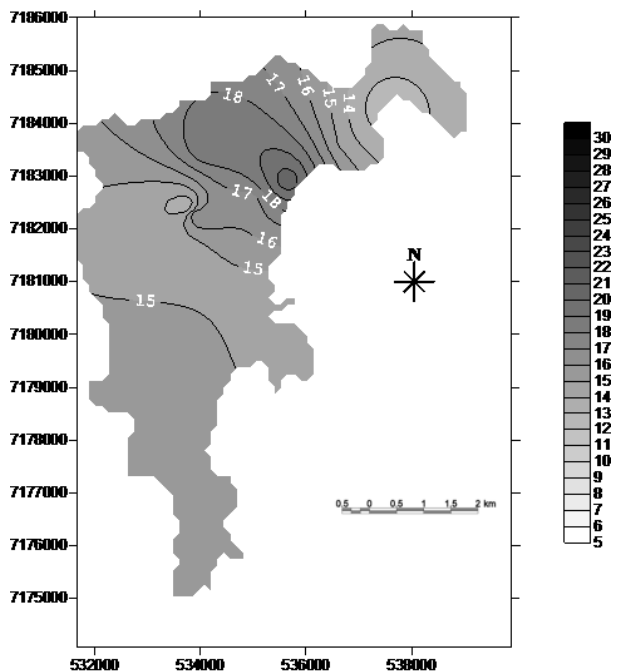

Figura 05: Temperatura $\left({ }^{\circ} \mathrm{C}\right)$ às 09 horas do dia 24/04/2008

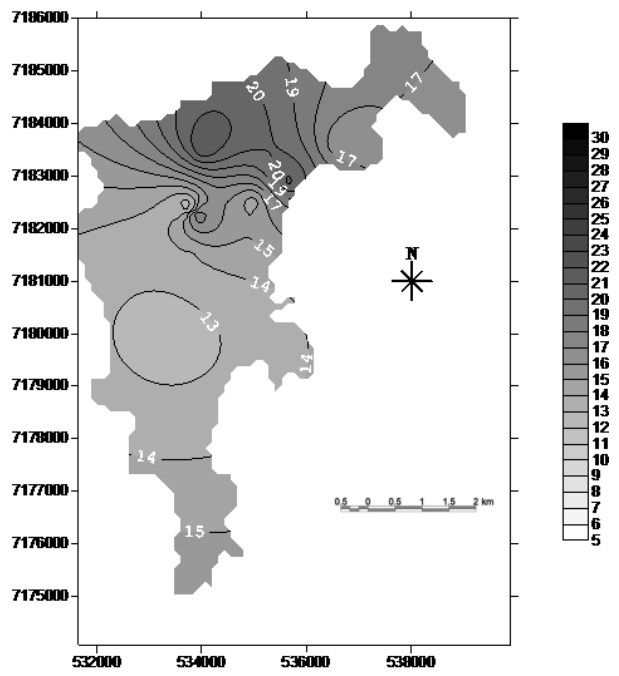

Figura 07: Temperatura $\left({ }^{\circ} \mathrm{C}\right)$ às 09 horas do dia 26/04/2008 


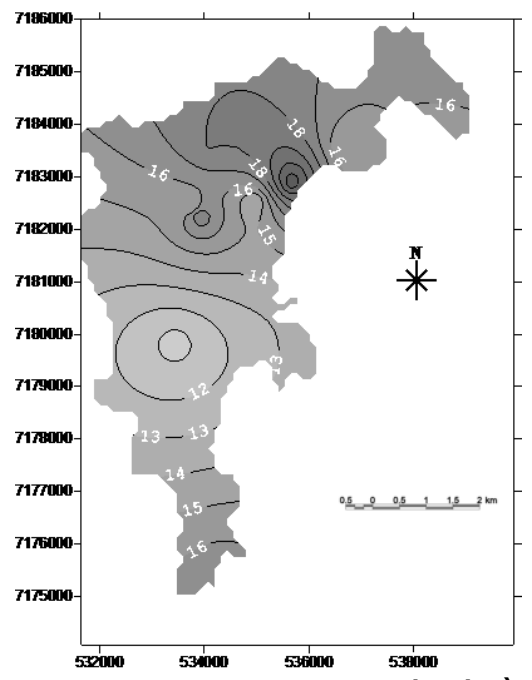

Figura 08: Temperatura $\left({ }^{\circ} \mathrm{C}\right)$ às 09 horas do dia $27 / 04 / 2008$

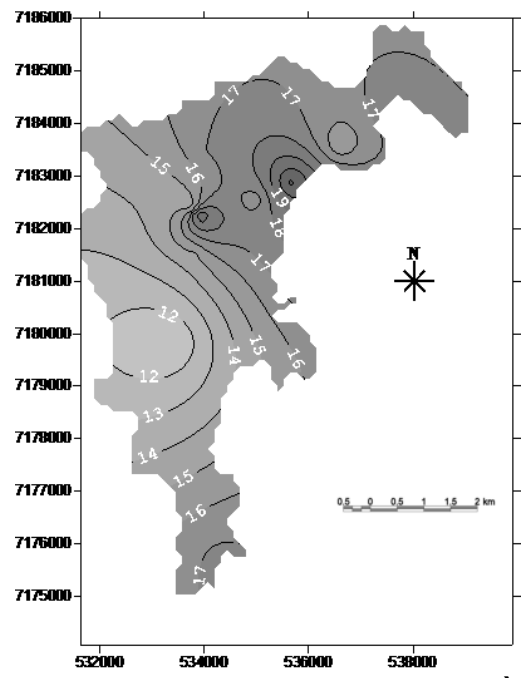

Figura 10: Temperatura $\left({ }^{\circ} \mathrm{C}\right)$ às 09 horas do dia 29/04/2008

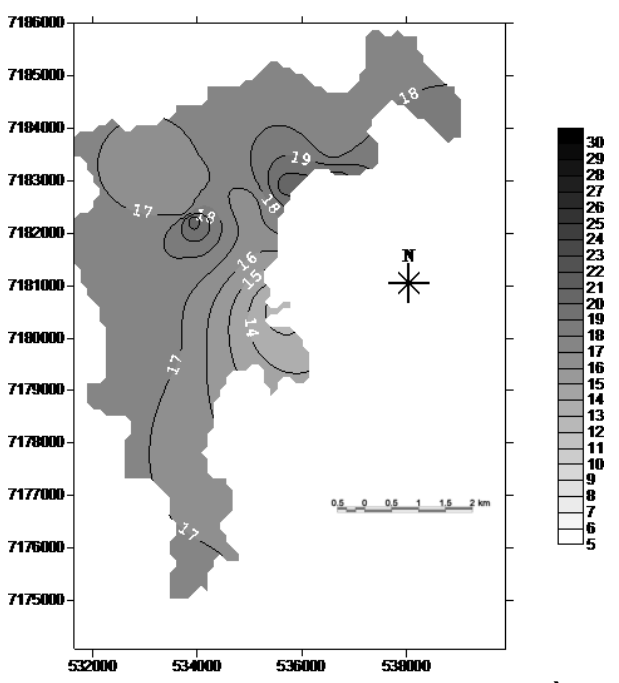

Figura 09: Temperatura $\left({ }^{\circ} \mathrm{C}\right)$ às 09 horas do dia 28/04/2008

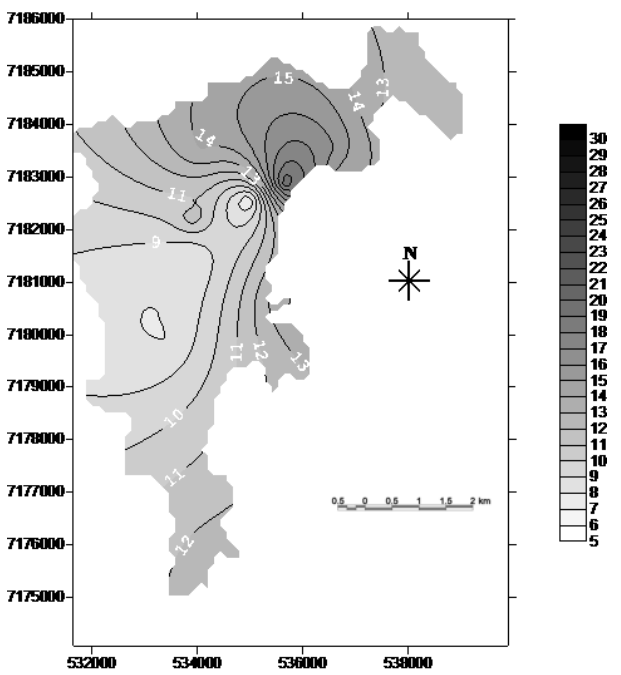

Figura 11: Temperatura $\left({ }^{\circ} \mathrm{C}\right)$ às 09 horas do dia 30/04/2008

Dessa forma, é possível perceber que a parte central da cidade, representada pelos pontos 4 a 8 , apresenta em todos os dias, maiores valores de temperatura, chegando a amplitudes em torno de $5,0{ }^{\circ} \mathrm{C}$, considerando pontos com temperaturas mais amenas (normalmente localizados em áreas com menor densidade populacional) e pontos com temperaturas mais elevadas (localizados em áreas com maior densidade populacional).

Deve-se ressaltar também, que a área mais quente possui maior concentração de atividades comerciais e menos áreas permeáveis, além da pouca vegetação, normalmente restritas a algumas praças de lazer. Já na região mais fria (pontos 4,5 e 6) existe um parque construído em uma antiga área degradada, com um lago artificial (Figura 03).

Em seguida, utilizando-se da mesma metodologia, são apresentadas figuras representativas das isotermas para o horário das 15 h00min. Vale 
ressaltar a importância de se ter, pelo menos, três leituras diárias, em que a leitura das 15 horas se torna uma das mais importantes, pois é nesse momento que a temperatura do ar tende a apresentar seus valores máximos durante as 24 horas do dia. Fato creditado ao máximo de radiação solar recebido nas horas que antecedem esse horário de leitura.

As Figuras 12 a 18 apresentam um padrão de distribuição espacial da temperatura, no horário das 15 horas, diferenciado em relação às Figuras 04 a 11 (horário das 09 horas). A variabilidade de dia para dia não é tão marcante e a distribuição espacial sofre uma maior variabilidade no mesmo dia.

Apesar de existirem dias em que a parte central da cidade está mais quente (Figuras 14, 15 e 17), tal ocorrência não é tão bem marcada como na leitura das 09 horas, pois a amplitude é bem menor (em torno de 2,5 ${ }^{\circ} \mathrm{C}$ ). Outra questão a ser analisada é que existem áreas fora da região central que apresentam temperaturas bastante elevadas, chegando a ser maiores do que na região central (Figuras 15, 18 e 19).

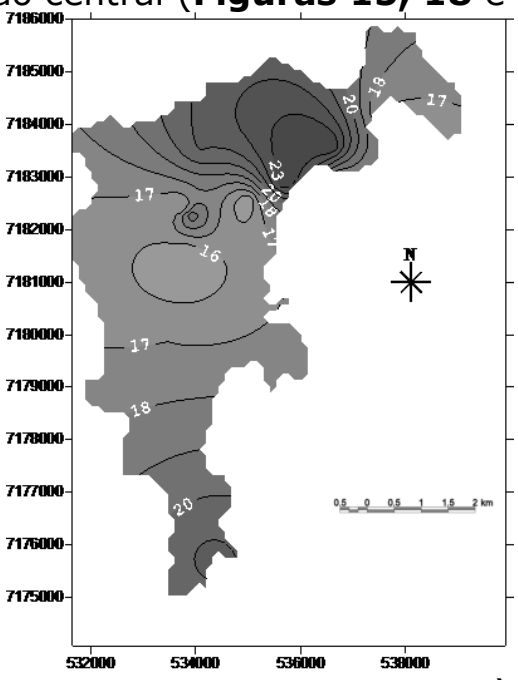

Figura 12: Temperatura $\left({ }^{\circ} \mathrm{C}\right)$ às 15 horas do dia 23/04/2008

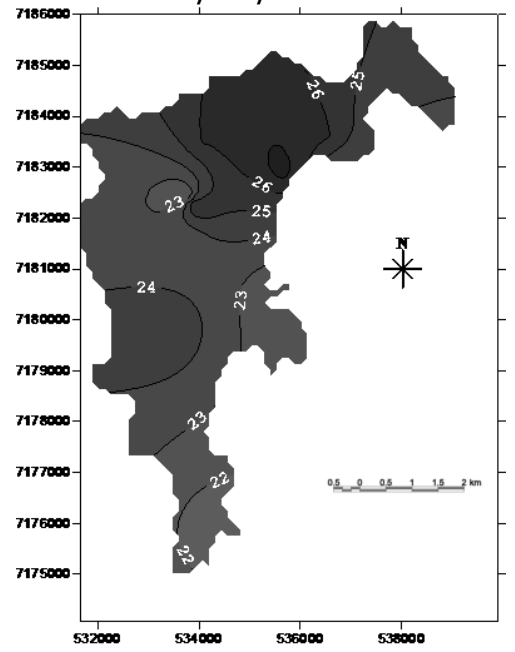

Figura 14: Temperatura $\left({ }^{\circ} \mathrm{C}\right)$ às 15 horas do dia 25/04/2008

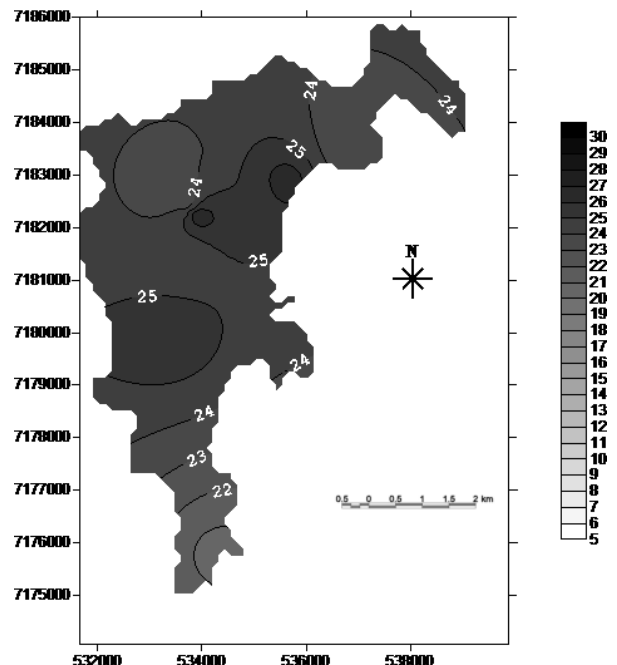

Figura 13: Temperatura $\left({ }^{\circ} \mathrm{C}\right)$ às 15 horas do dia 24/04/2008

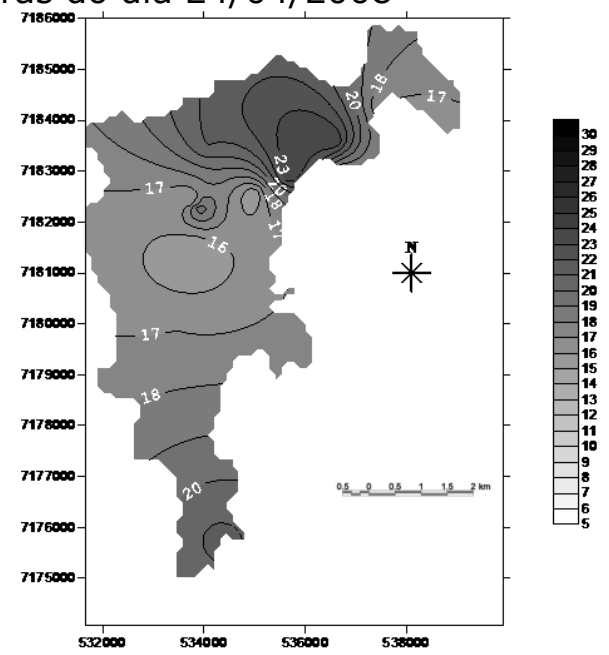

Figura 15: Temperatura $\left({ }^{\circ} \mathrm{C}\right)$ às 15 horas do dia 26/04/2008 


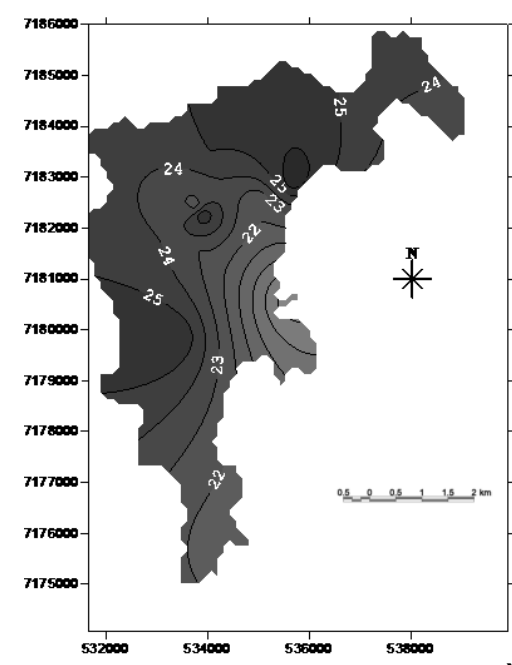

Figura 16: Temperatura $\left({ }^{\circ} \mathrm{C}\right)$ às 15 horas do dia 27/04/2008

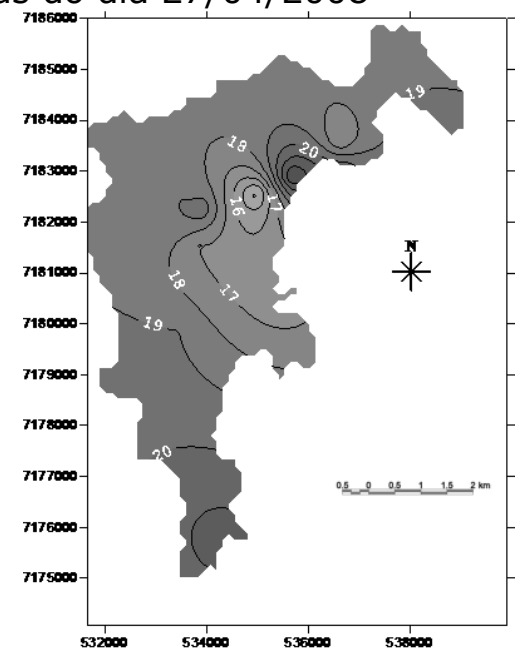

Figura 18: Temperatura $\left({ }^{\circ} \mathrm{C}\right)$ às 15 horas do dia 29/04/2008

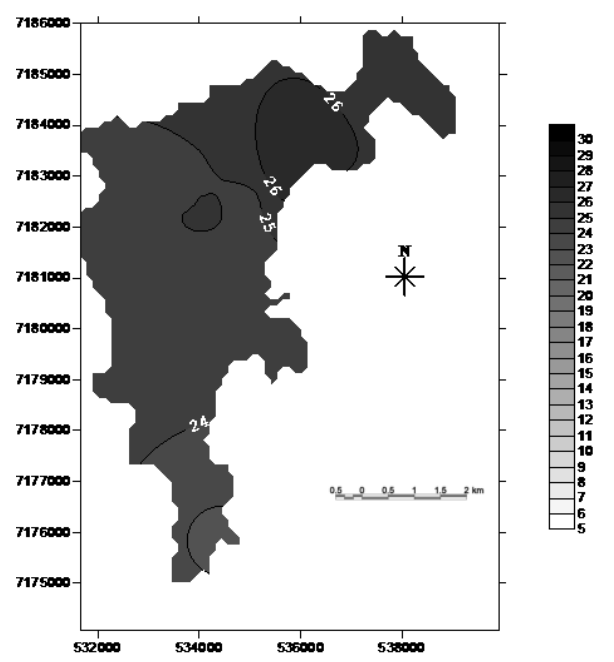

Figura 17: Temperatura $\left({ }^{\circ} \mathrm{C}\right)$ às 15 horas do dia 28/04/2008
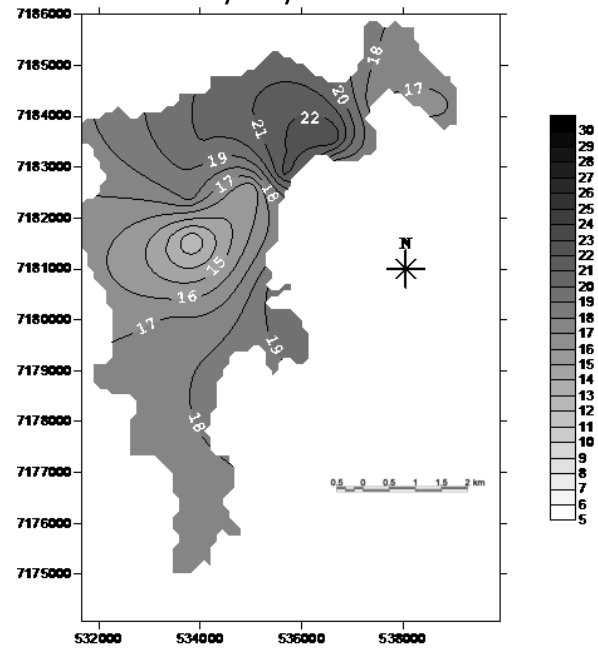

Figura 19: Temperatura $\left({ }^{\circ} \mathrm{C}\right)$ às 15 horas do dia 30/04/2008

Desta forma, apesar de ainda existir uma tendência de temperaturas mais elevadas na parte central da cidade, isto não ocorre de maneira homogênea, dificultando a conclusão da ocorrência de um local específico para ilha de calor.

Por fim, os dados de temperatura referente ao horário das 21 horas são avaliados através das Figuras $\mathbf{2 0}$ a 27, apresentando sua variabilidade temporal e espacial. Através destas figuras, percebe-se que as amplitudes térmicas são bem marcadas. Os valores máximos e mínimos da temperatura apresentam uma variabilidade que chega a $6,0^{\circ} \mathrm{C}$ (de região para região), como é o caso da Figuras 20, 21, 22 e 27. Entretanto, existe uma inversão nas áreas com maior e menor temperatura, pois a parte central da cidade, que havia demonstrado maiores temperaturas durante o dia, principalmente na parte da manhã, apresenta valores de temperaturas mais amenas à noite. 


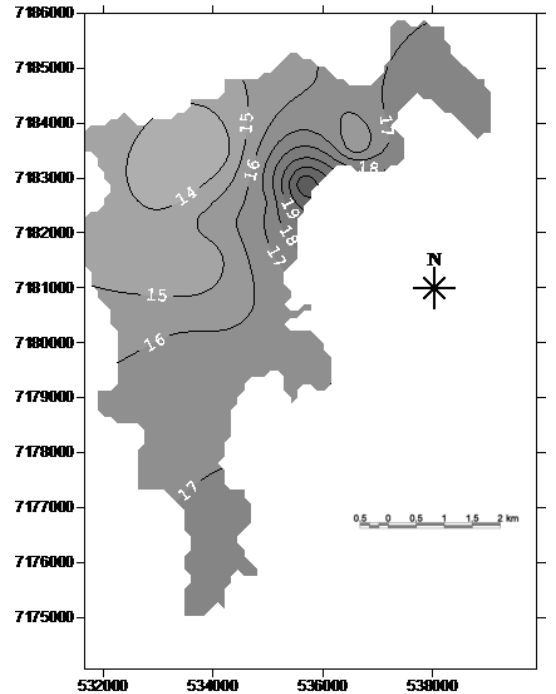

Figura 20: Temperatura $\left({ }^{\circ} \mathrm{C}\right)$ às 21 horas do dia 23/04/2008

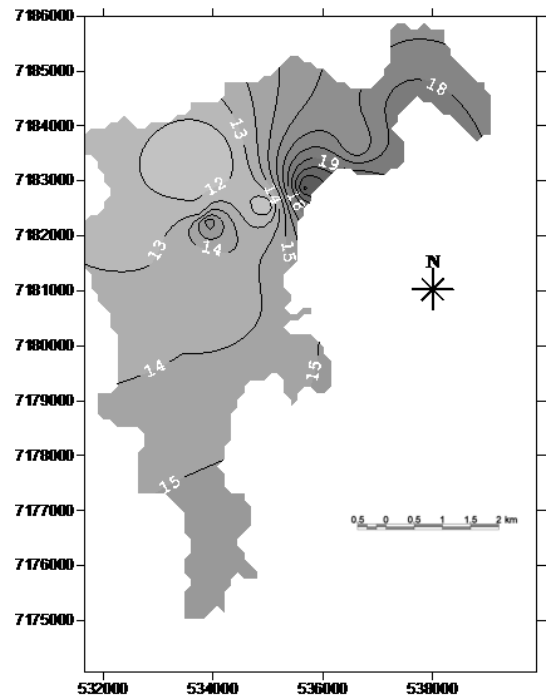

Figura 22: Temperatura $\left({ }^{\circ} \mathrm{C}\right)$ às 21 horas do dia 25/04/2008

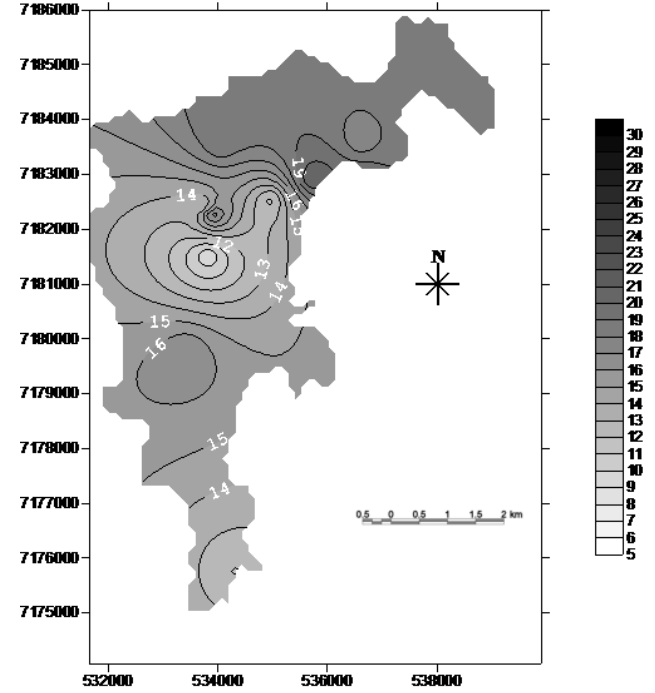

Figura 21: Temperatura $\left({ }^{\circ} \mathrm{C}\right)$ às 21 horas do dia 24/04/2008

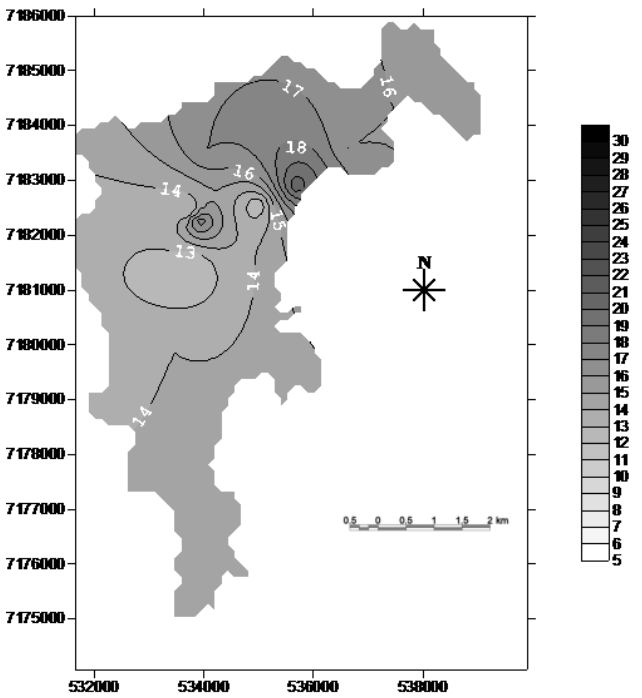

Figura 23: Temperatura $\left({ }^{\circ} \mathrm{C}\right)$ às 21 horas do dia 26/04/2008 


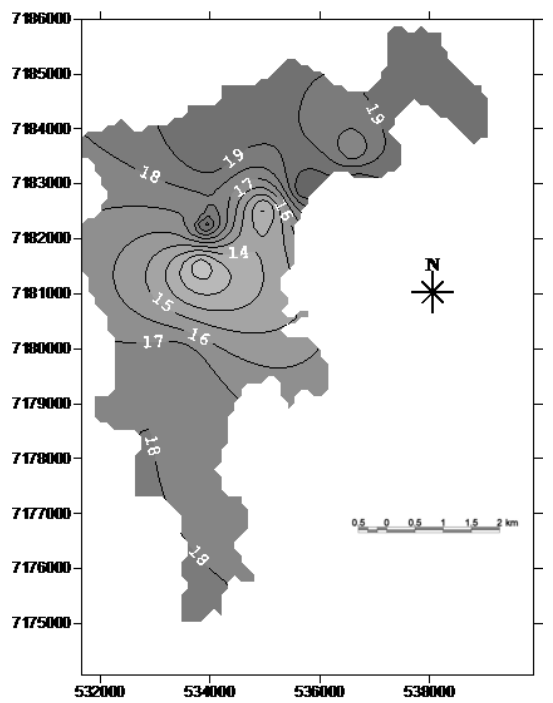

Figura 24: Temperatura $\left({ }^{\circ} \mathrm{C}\right)$ às 21 horas do dia $27 / 04 / 2008$

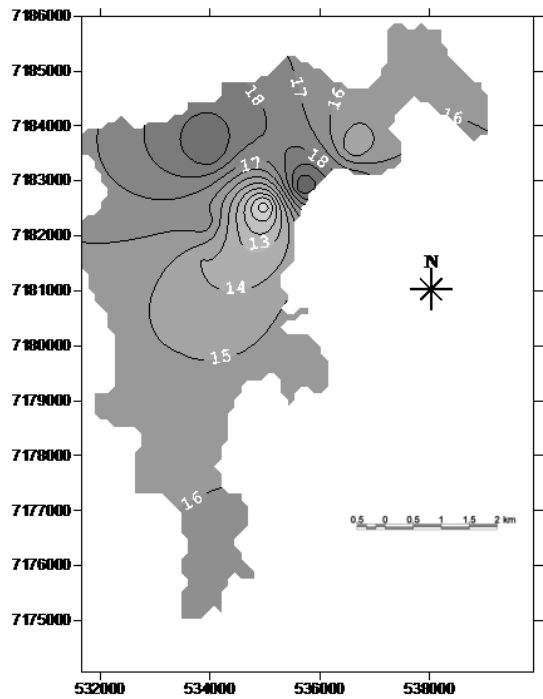

Figura 26: Temperatura $\left({ }^{\circ} \mathrm{C}\right)$ às 21 horas do dia 29/04/2008

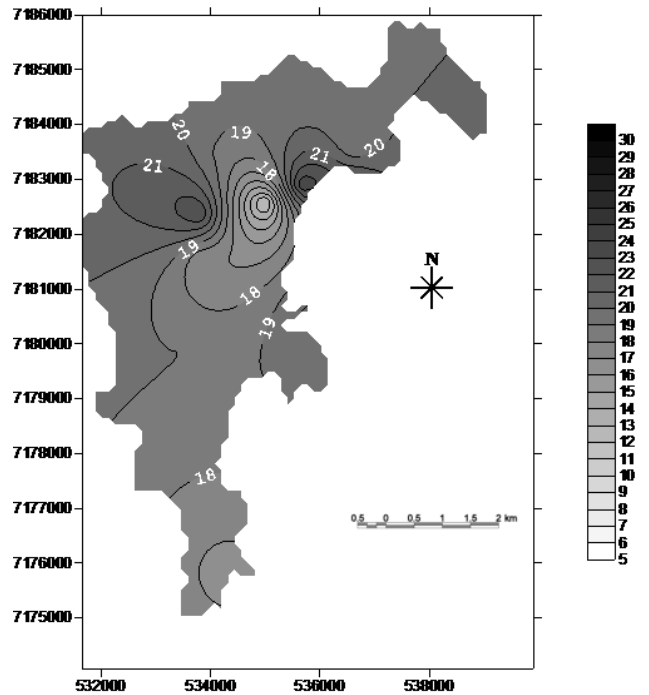

Figura 25: Temperatura $\left({ }^{\circ} \mathrm{C}\right)$ às 21 horas do dia 28/04/2008

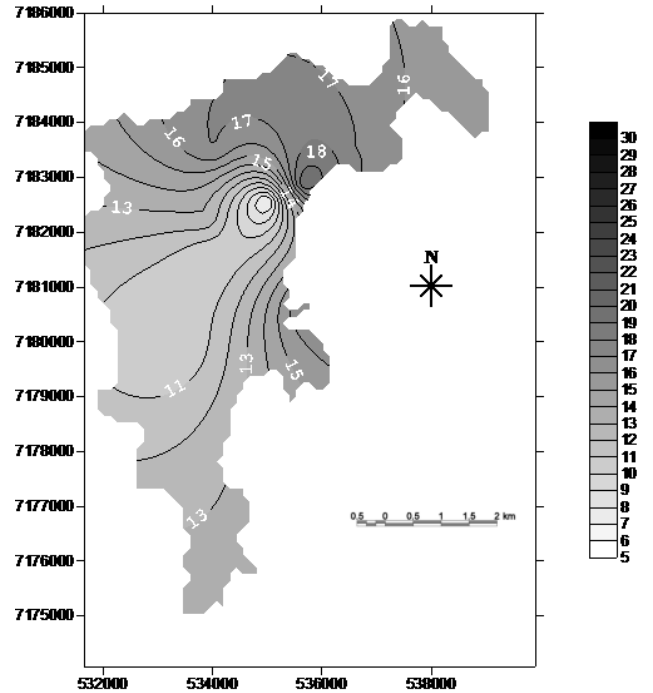

Figura 27: Temperatura $\left({ }^{\circ} \mathrm{C}\right)$ às 21 horas do dia 30/04/2008

O padrão dipolo termal observado próximo a área central, pode ser explicado por dois fatores: o primeiro seria relativo a disposição das vertentes, pois o ponto de coleta que apresenta o valor mais baixo está localizado em uma vertente voltada para leste, portanto a mesma recebeu radiação solar direta apenas até no início da tarde; o segundo fator, relacionado a área mais quente, é ocasionado devido ao ponto de coleta se localizar na região com maior adensamento urbano (área central) e que recebeu radiação solar por um maior número de horas, pois nessa região o sítio urbano apresenta relevo mais plano por pertencer a planície formada nas proximidades do Rio das Antas, maior bacia localizada dentro da área urbana, que também tem altitudes inferiores às áreas circunvizinhas. 


\section{CONCLUSÕES}

A evolução dos estudos centrados no planejamento urbano brasileiro e sua interação com os aspectos climáticos é, pelo menos na Geografia nacional, um tema recente (mais ou menos 30 anos), mas que levanta questões importantes na identificação de problemas socioambientais urbanos. As proposições metodológicas existentes permitem uma avaliação do ambiente urbano de forma ampla.

Apesar dos problemas (políticos, em sua maioria) de implementação de propostas oriundas de estudos acadêmicos, a contribuição da Geografia ao planejamento das cidades, emerge como possível resposta às dificuldades encontradas pela sociedade humana em ocupar o espaço urbano e manter sua qualidade de vida, principalmente na discussão centrada no conforto ambiental, de forma mais abrangente.

A cidade de Irati, apesar dos seus mais de 100 anos de história oficial, apresenta uma evolução urbana bastante complexa, sem muita lógica social e destituída de um prévio planejamento. Os aspectos físicos da área (relevo, vegetação, água e orientação das vertentes) são os principais influenciadores da ocupação do espaço, pois as atividades econômicas são pouco consideradas.

Este trabalho não se propõe a ser uma forma de planejamento urbano para Irati, seria uma pretensão difícil de ser alcançada através dos objetivos propostos, que se limitaram à identificação de diferenças no campo térmico do perímetro urbano de Irati. Entretanto, as análises efetuadas podem ser referências para a realização de um planejamento mais eficaz, em que a identificação de áreas mais e menos aquecidas, pode influenciar, por exemplo, na construção de parques e propostas de despoluição do ar.

Nesse sentido, com o principal objetivo de identificar aspectos sociais e naturais que estejam influenciando a diferenciação espaço-temporal da temperatura do ar em Irati, foi possível monitorar dados pelo período de sete dias no outono iratiense. Este monitoramento permitiu concluir que o relevo é um dos aspectos mais importantes na diferenciação térmica, pois os locais mais altos apresentaram temperaturas mais elevadas, na maior parte dos dias e horários monitorados.

Também foi possível perceber que existe uma influência marcante da distribuição de atividades urbanas, tais como: moradia; comércio; lazer e serviços. A parte central da cidade se localiza numa região mais plana e num topo de vale, possibilitando melhores condições de uso da terra.

Dessa forma, a influência do relevo é novamente percebida nos resultados obtidos, mas, dessa vez, de uma forma mais ampla, em que as construções existentes atuam de forma integrada, justificando a escolha do tema central desta pesquisa (variabilidade do campo térmico), tendo suas causas e efeitos relacionadas à disposição das vertentes e nas cotas altimétricas concernentes ás relações topo/fundo de vale.

Contudo, os experimentos realizados demonstraram também que as atividades sócio-econômicas devem ser melhor analisadas, pois as áreas de maior concentração da atividade comercial (centro da cidade) apresentaram temperaturas mais elevadas, apesar de os aspectos físicos poderem estar influenciando mais do que os sociais. Da mesma forma, a região onde estão 
localizadas as atividades industriais não apresenta uma influência marcante na definição da variação do campo térmico, fato normalmente não foi percebido.

Entende-se que novas investigações devem ser feitas, pois a região de Irati ainda é pouco explorada dentro desta temática, mesmo porque o objetivo do presente estudo foi apresentar um diagnóstico preliminar da diferenciação térmica da cidade, centrado em observações sistemáticas das oscilações da temperatura do ar em diferentes horários (09, 15 e 21 horas).

A presente pesquisa revelou que a área de estudo necessita de uma investigação mais aprofundada acerca da formação de ilhas de calor/frescor, embora os resultados tenham evidenciado a conformação da mesma. A ilha de calor evidenciada nos resultados foi observada na área central da cidade, fato corriqueiro em pesquisa sobre clima urbano, mas apresentou uma dinâmica diferenciada, tanto na sua amplitude, quanto no comportamento diário.

Tal fato se prende à identificação do seu desaparecimento no período noturno, evidenciando uma possível influência da orientação da vertente (leste) que recebe radiação solar até o início da tarde, possibilitando um resfriamento mais rápido até o início da noite. Por outro lado, a dinâmica climática regional, talvez seja mais representativa na variabilidade da temperatura local (área urbana).

As inferências aqui expostas são uma convergência entre a análise dos dados e o conhecimento da dinâmica climática regional, possibilitando avançar nos estudos e contribuir no planejamento urbano da cidade, buscando um melhor conforto térmico.

A climatologia geográfica pode e deve ser utilizada como ferramenta de análise do ambiente urbano, pois possui técnicas e metodologias que explicam a complexidade do ambiente urbano de forma satisfatória. Ao se analisar o campo térmico de uma cidade de porte pequeno (caso estudado), já é possível identificar alguns problemas no uso e ocupação da terra, mas se os estudos avançarem para diagnósticos mais complexos, utilizando outras variáveis climatológicas, o auxílio ao planejamento urbano será incontestável.

\section{AGRADECIMENTOS}

Agradecemos aos alunos do Curso de Geografia que prontamente se colocaram à disposição para efetuarem a coleta dos dados de temperatura do ar. Sem eles, este trabalho não seria possível.

\section{REFERÊNCIAS BIBLIOGRÁFICAS}

BRANDÃO, A. M. P. M. O clima urbano da cidade do Rio de Janeiro. Tese (Doutorado em Geografia). Departamento de Geografia, FFLCH/USP. São Paulo, 1996. 362f.

CPTEC, 2010. Climanalise, vol. $23, \quad n$. 04 (http://climanalise.cptec.inpe.br/ rclimanl/boletim). Acesso: 11/06/2010.

FREITAG, B. Teorias da Cidade. Campinas: Papirus, 2006, 190p. 
INSTITUTO PARANAENSE DE DESENVOLVIMENTO ECONÔMICO E SOCIAL (IPARDES). Perfil dos municípios: 2008. Disponível em $<$ http://ipardes.gov.br/perfil municipal/MontaPerfil.php?Municipio=84500\&btOk =ok>. Acessado em: 27 Jul. 2008.

LEFEBVRE, H. O Direito à Cidade. Tradução de Rubens Eduardo Frias. São Paulo: Centauro, 2001, 144p.

LOMBARDO, M. A. Ilhas de Calor nas Metrópoles: o caso de São Paulo. São Paulo: HUCITEC, 1985.

MENDONÇA, F. A. O clima e o Planejamento urbano de cidades de Porte Médio e Pequeno: Proposição Metodológica para Estudo e sua Aplicação à Cidade de Londrina/PR. Tese (Doutorado em Geografia Física) FFLCH/USP, São Paulo, 1995, $298 \mathrm{f}$.

MENDONÇA, F. S. A. U. - Sistema Socioambiental Urbano: uma abordagem dos problemas socioambentais da cidade. In: MENDONÇA, F. (org.). Impactos Socioambientais Urbanos. Curitiba: Editora da UFPR, 2004. p. 185-207.

MONTEIRO, C. A. F. Teoria e Clima Urbano. São Paulo: IGEO/USP, 1976.

MONTEIRO, C.A.F. Por um suporte teórico e prático para estimular estudos geográficos do clima urbano do Brasil. GEOSUL - Revista do Departamento de Geociências da UFSC, Volume V, no 9, p. 07-19. Editora da UFSC, Santa Catarina, 1990.

MONTEIRO, C. A. F. Teoria e Clima Urbano: um projeto e seus caminhos. In: MONTEIRO, C. A. F. \& MENDONÇA, F. (org.). Clima Urbano. São Paulo: Contexto, 2003, p. 9-67.

ORREDA, J. M. Irati. Vol. 3, Irati: Edipar, 1991.

PREFEITURA MUNICIPAL DE IRATI. O município: clima. 2008. Disponível em: $<$ http://www.irati.pr.gov.br/municipio/clima.asp > . Acessado em 17 Jul. 2008. SANTOS, Milton. "Flexibilidade Tropical". Arquitetura e Urbanismo, 38, outnov., pp. 44-45., 1991.

SANTOS, M. Por uma Economia Política da Cidade. São Paulo, Hucitec/Educ., 1994.

SANTOS, M. A Urbanização Brasileira. $5^{a}$ Edição, $1^{\text {a }}$ Reimpressão, São Paulo: Editora da USP, 2008, 176 p.

SOUZA, M. L. de. Mudar a Cidade: uma introdução crítica ao planejamento e à gestão urbanos. $4^{a}$ Edição. Rio de Janeiro: Bertrand do Brasil, 2006, 560p.

TARIFA, J. R. Análise comparativa da temperatura e umidade na área urbana e rural de São José dos Campos. IGEO/USP, 1977. (Série Climatologia 07). 
